\title{
NOTES ON PIESMA CINEREA SAY IN NEW JERSEY (HEMIPTERA).
}

\author{
By Harry B. Weiss and Ralph B. Lott.
}

New Brunswick, N. J.

This species occurs throughout New Jersey being locally common, and according to Smith (Insects of New Jersey) on horse-chestnut, under the bark of Platanus, etc. It has been mentioned frequently in literature but very little has been recorded concerning its various food plants and life history. Parshley (Canadian Entom. Feb. 1917, p. 47) mentions its occurrence in ocean drift at Beach Bluff, Mass., on June 21. Osborn and Drake (Bull. 8, vol. 11, no. 4, p. 219) state that it is common throughout Ohio under the bark of sycamore and horse-chestnut during the winter. Summers (Bull. Agric. Exp. Sta. Tennessee, vol. 4 , no. 3 , p. 90, 1891) has observed it "so abundant on the young leaves and flowers of grape as to do considerable damage." In the recently published "Hemiptera of Connecticut" it is listed from several localities and the statement is made that it is rather rare in the northeast. Parshley in his "Fauna of New England, Hemiptera-Heteroptera" (Occas. Papers Boston Soc. Nat. Hist., vol. 7, p. 53) gives localities in Massachusetts, Rhode Island and Connecticut. In the "Insects of Florida" by Barber (Bull. American Mus. Nat. Hist., vol. 33, Art. xxxi, pp. 495-535, 1914) it is listed from a single locality. Van Duzee (Cat. Hemip. America north of Mexico) lists it from Ontario, New York, Pennsylvania, North Carolina, Florida, Ohio, Illinois, Kansas, Colorado and California and McAtee (Bull. Brooklyn Entom. Soc., vol. 14, p. 86, 1919) summarizes its distribution as a transcontinental species by giving its range as from the state of Washington, Ontario and Massachusetts south to Texas, Florida and to Linares and Tampico, Mexico.

From the foregoing it is evident that the species is common and widely distributed. In New Jersey we have found it feeding on the flower heads of rush (Scirpus atrovirens) at Monmouth Junction, June 17, Bound Brook, August 9 and at Dayton, August 1, Riverton, August 9 and Moorestown, July 25 feeding 
on Amaranthus retroflexus L., a weed commonly known as red root or pink root and sometimes very plentiful in cultivated orchards and fields.

At Moorestown, New Jersey, on July 25, where most of our observations were made, many plants of Amaranthus retroflexus were observed to be heavily infested with all nymphal stages and adults. Many eggs were present also. The upper leaf surfaces were mottled and spotted with white and some entire plants were almost white from top to bottom due to the combined attacks of hundreds of nymphs and adults. The injury appeared to be most severe at the tips of the plants and here the flowers and young, tender leaves hung limp and white. Eggs and empty egg shells were quite plentiful on this date. Some leaves carried as many as 18 or $20 \mathrm{eggs}$, anywhere on the lower surface and some of the flower heads were full of eggs. A few eggs were found on the upper leaf surfaces close to and parallel with the main ribs and side veins, sometimes in the axils of the veins. Others were found attached to the portions of the leaves between the side veins.

The pearly-white eggs appear to be deposited singly and fastened lightly to the leaf tissue and sides of the ribs and veins. The nymphs inhabit the lower leaf surfaces and flower heads, but the adults may occur on any portion of the plant. The nymphs are green or greenish with white markings and their color blends with that of the injured leaves. Whereas at Moorestown on July 25, many eggs and all stages were present, adults and last stage nymphs greatly outnumbered the other forms. It appeared at that time as if a new brook of adults had just gotten under way. Later in the season or on August 30, quite a few adults were present, a very few last stage nymphs and a very few eggs. Many of the adults appeared in to copulation on the flower heads.

Adult. This was described by Say (Complete Writings vol. 1, p. 349) as follows.

" $T$. cinerea-Not dilated, hemelytra with six or seven marginal spots.

Inhabits United States. 
Body gray; not dilated on the margin; with much dilated punctures; head deeply bifid at tip and with a short robust spine between the eye and antennæ, basal joint spherical, abruptly smaller at base, second joint not longer than the first and less dilated; thorax with four elevated lines, obsolete behind; anterior lateral margin a little dilated; hemelytra covered, like the thorax with dilated approximate punctures, and having on the lateral margin a series of six or seven black spots; beneath grayish, more or less varied with brown; venter brownish, with spots or lines of grayish. Length to tip of hemelytra more than one-tenth of an inch. In form much resembling T. cardui $\mathrm{F}$. It is not uncommon."

The coloration of the adult is variable and the color varieties grade into each other with one exception, this being the variety inornata described by McAtee (Bull. Brooklyn Entom. Soc., vol. 14, 1919) and said by him to be distinct and always separable. 

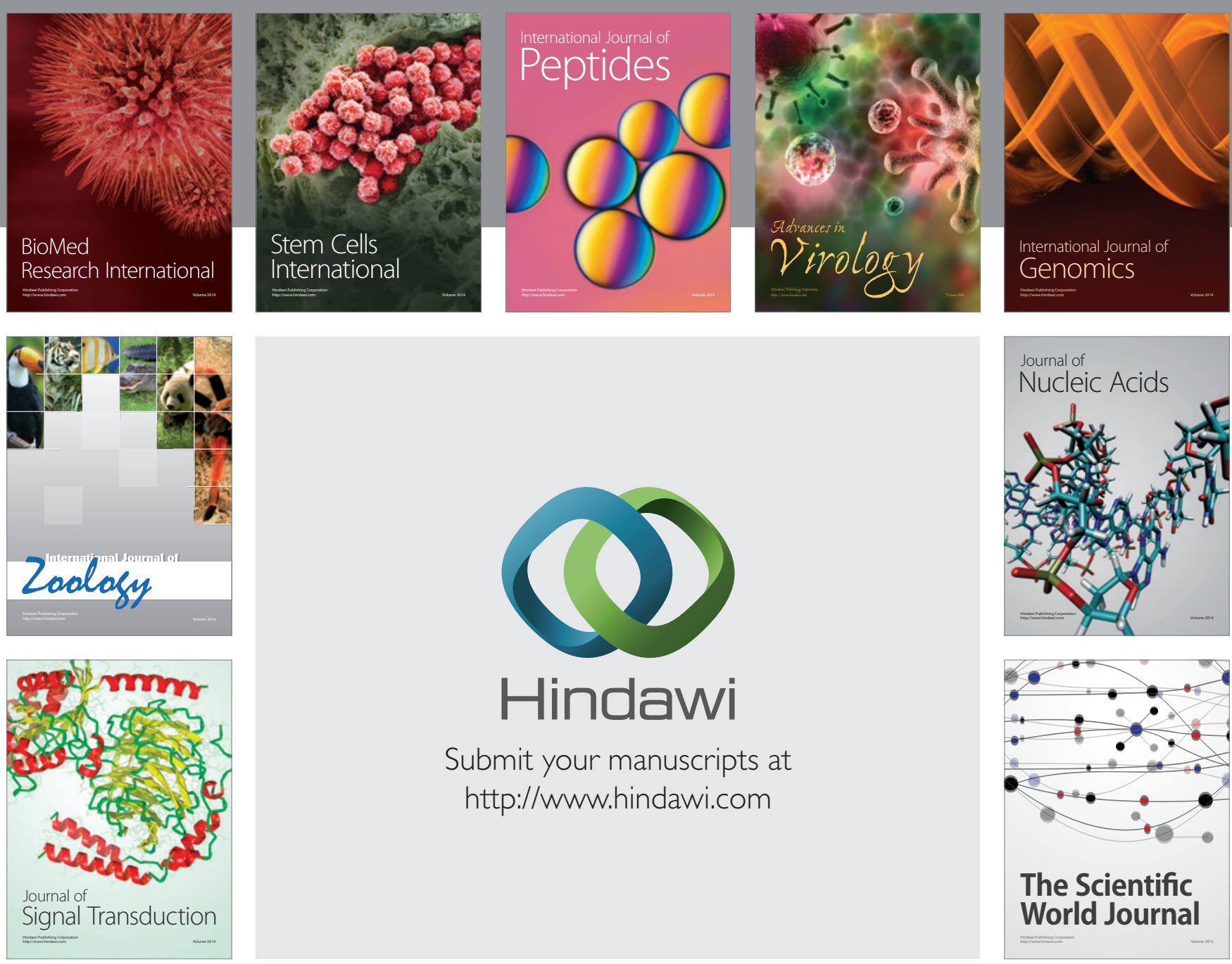

Submit your manuscripts at

http://www.hindawi.com
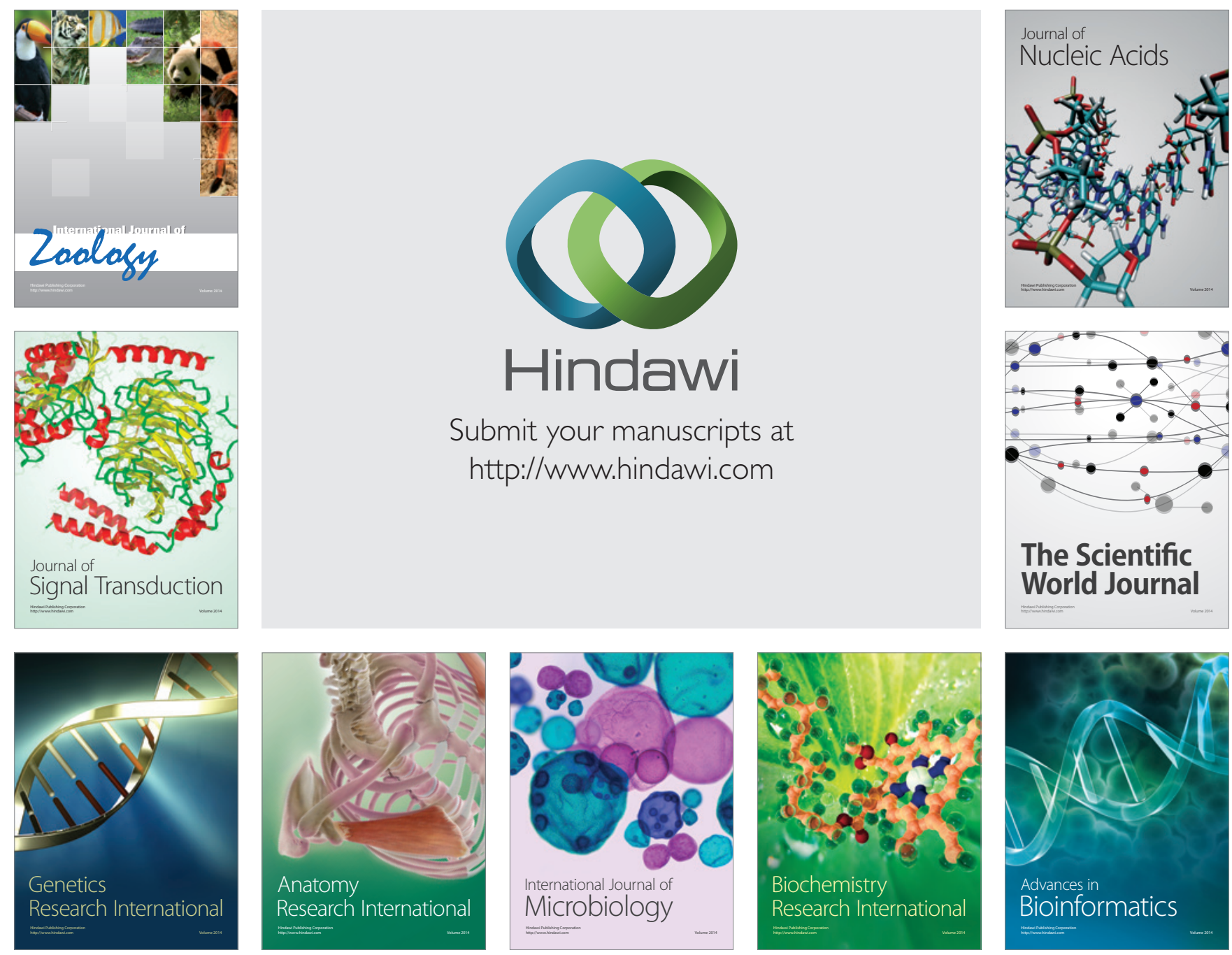

The Scientific World Journal
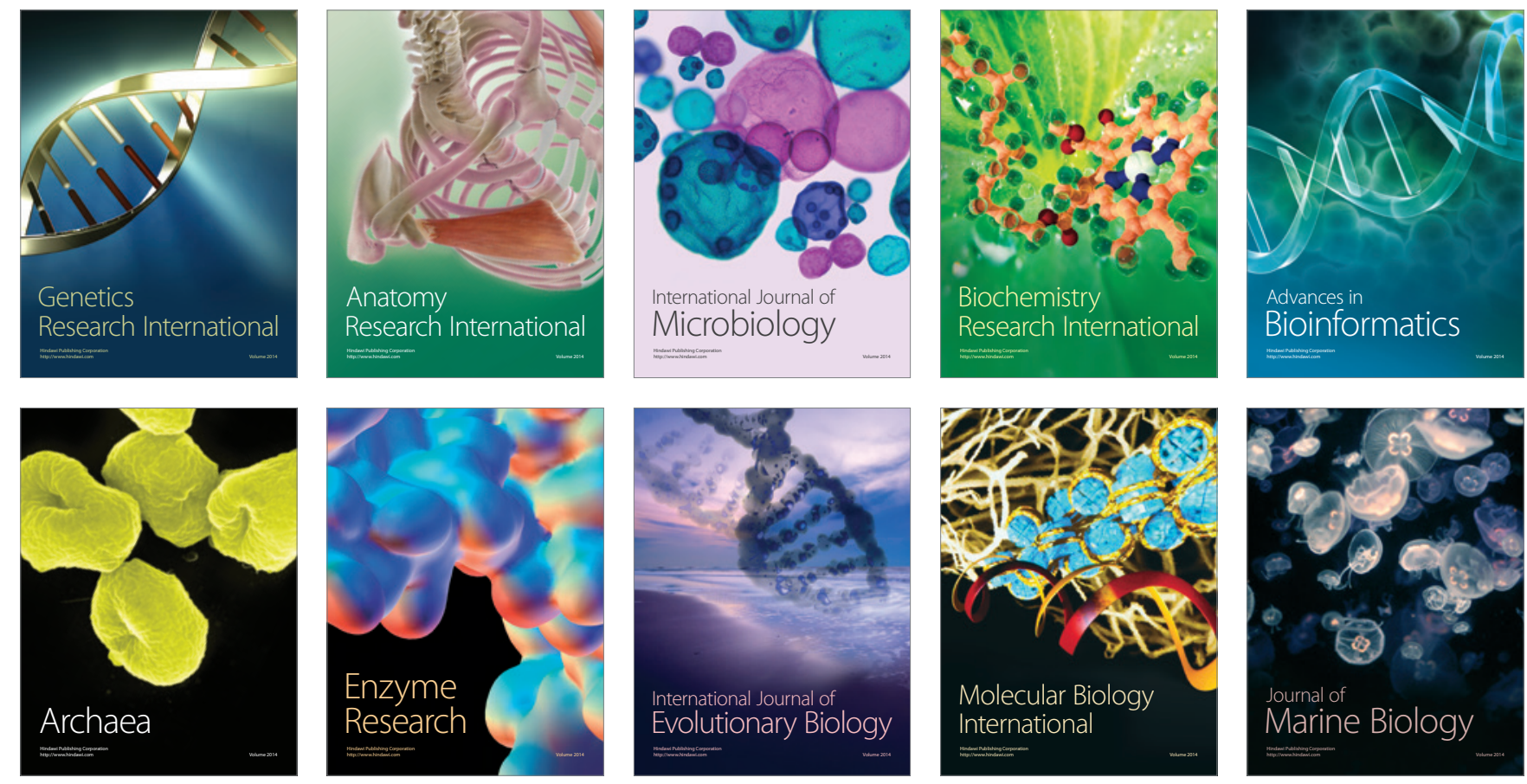